\title{
Design and synthesis of iridium(III) azacrown complex: application as a highly sensitive metal cation phosphorescence sensor
}

\author{
Mei-Lin Ho, ${ }^{a}$ Fu-Ming Hwang, ${ }^{b}$ Pei-Nung Chen, ${ }^{b}$ Ya-Hui Hu, ${ }^{a}$ Yi-Ming Cheng, ${ }^{a}$ Kung-Shih Chen, ${ }^{a}$ \\ Gene-Hsiang Lee, ${ }^{a}$ Yun $\mathrm{Chi}^{* b}$ and Pi-Tai Chou $* a$
}

\author{
Received 22nd August 2005, Accepted 27th October 2005 \\ First published as an Advance Article on the web 18th November 2005 \\ DOI: 10.1039/b511943j
}

\begin{abstract}
A new metal cation probe 1 bearing a central Ir(III) element and 1-aza-15-crown-5-ether substituted pyridyl pyrazolate as the chelate was synthesized. The octahedral molecular structure of $\mathbf{1}$ was confirmed using single crystal X-ray diffraction analyses. Subsequent photophysical study showed yellow-green emission at $\sim 560 \mathrm{~nm}$ in both fluid solution and solid state at room temperature. Remarkable differentiation in spectral properties upon metal cation (e.g. $\left.\mathrm{Ca}^{2+}\right)$ complexation makes complex $\mathbf{1}$ a highly sensitive phosphorescence probe.
\end{abstract}

\section{Introduction}

Detection of alkali or alkaline earth ions has great potential for practical applications in areas such as analytical chemistry, environmental chemistry and the biological sciences. ${ }^{1}$ One method is to use the so-called chemosensor that shows the basic molecular configurations such as chromophore-receptor or chromophorespacer-receptor. As the receptor can selectively bind with the guest cations, measurable and reversible changes in color and/or luminescence can be detected at the signalling unit (i.e. chromophore) linking to the receptor, which allows the recognition and quantification of the metal cation by conventional spectroscopic methods. ${ }^{2}$ A common design contains a crown ether to serve as the receptor, together with an organic dye or other metal based fluorophores. ${ }^{3}$ Recently, extension was made to systems with thirdrow transition-metal complexes. ${ }^{4}$ Work by a number of groups, mainly pioneered by Schanze and co-workers, ${ }^{5}$ has established the importance of utilizing long-lived phosphorescence. Typical signalling involves the switching between non-emissive intraligand ( $\left.{ }^{3} \mathrm{IL}\right) \pi \pi^{*}$ and metal-to-ligand charge transfer ( $\left.{ }^{3} \mathrm{MLCT}\right)$ states, ${ }^{6}$ so that a positive luminescent response $v s$. concentration of cation can be obtained. Moreover, it may allow the design of "light-controlled ion switches", for which the cation ejection from the crown ether can be triggered by the effective reduction of electron donation at the receptor on excitation of the nearby chromophore.

In this article, we present a novel system in which an azacrown receptor is attached to the pyridyl pyrazolate chelate of a heteroleptic Ir(III) complex. This design provides three inherent advantages. First, the Ir(III) metal atom forms a highly stable, octahedral coordinated structure and induces strong phosphorescent emission due to the heavy atom effect. Moreover, the ancillary cyclometalated phenyl pyrazole ligands, for which the $\pi \pi^{*}$ energy levels are far higher than those of the respective MLCT and other ligand-

${ }^{a}$ Department of Chemistry, National Taiwan University, Taipei, 106, Taiwan. E-mail: chop@ntu.edu.tw

${ }^{b}$ Department of Chemistry, National Tsing Hua University, Hsinchu, 300, Taiwan.E-mail:ychi@mx.nthu.edu.tw centered $\pi \pi^{*}$ excited states, ${ }^{7}$ enable both the HOMO and LUMO to reside predominantly on the azacrown substituted pyridyl pyrazolate segment. This architecture enhances the effectiveness of this design over others having more delocalized electronic configurations; the latter should be less capable of recognizing the cation due to the spreading of their electronic perturbation over the whole complex. Thirdly, the azacrown fragment is attached to an anionic pyrazolate chelate ligand, forming a neutral $\operatorname{Ir}(\mathrm{III})$ metal complex. Such a charge-neutral characteristic is similar to that of the $\operatorname{Re}(\mathrm{I})$ and $\mathrm{Pt}(\mathrm{II})$ based sensor complexes, but is in sharp contrast to most of the Ru(II) based polypyridyl sensors, ${ }^{8}$ for which the net cationic charge on the overall metal complex is expected to reside, in part, at the azacrown ether site, giving a much reduced sensitivity in recognizing metal cations. ${ }^{9}$

\section{Experimental}

\section{General information and materials}

Elemental analyses and mass spectra (operating in FAB mode) were carried out at the NSC Regional Instrument Centre at the National Chiao Tung University, Taiwan. ${ }^{1} \mathrm{H}$ and ${ }^{13} \mathrm{C}$ NMR spectra were recorded on a Varian Mercury 400 or an Inova$500 \mathrm{MHz}$ instrument; chemical shifts are quoted with respect to an internal standard, $\mathrm{Me}_{4} \mathrm{Si}$. All synthetic manipulations were performed under a $\mathrm{N}_{2}$ atmosphere, while solvents were used as received. Synthesis of 1-[4-(1,4,7,10-tetraoxa-13-aza-cyclopentadec13-yl)-phenyl] ethanone follows the procedures reported by Okahara and co-workers, ${ }^{10}$ using the starting materials $4-N, N$-bis(2hydroxyethyl)aminoacetophenone and triethylene glycol di( $p$ toluenesulfonate). Triethylene glycol $\mathrm{di}(p$-toluenesulfonate) was prepared using the literature method, ${ }^{11}$ while 1-phenyl-3,5dimethyl pyrazole (pdpz)H was prepared from the condensation of phenyl hydrazine hydrochloride with acetylacetone according to literature procedures. ${ }^{12}$ Treatment of (pdpz)H with $\mathrm{IrCl}_{3} \cdot n \mathrm{H}_{2} \mathrm{O}$ in refluxing methoxyethanol afforded the chloride bridged dimer $\left[(\mathrm{pdpz})_{2} \mathrm{IrCl}\right]_{2}$ in $75 \%$ yield; ${ }^{13}$ it was then used for subsequent reactions without further purification. 


\section{Synthesis of [3-(4-aza-15-crown-5-phenyl)pyridyl(1,3-dione)]}

To a stirred suspension of $\mathrm{NaH}(0.75 \mathrm{~g}, 31.3 \mathrm{mmol})$ in $\mathrm{THF}$ (40 mL), was slowly added $15 \mathrm{~mL}$ of THF solution of 1-[4(1,4,7,10-tetraoxa-13-aza-cyclopentadec-13-yl)-phenyl]-ethanone $(2.6 \mathrm{~g}, 7.8 \mathrm{mmol})$ at room temperature. The solution was heated to reflux, and ethyl picolinate $(2.0 \mathrm{~mL}, 15 \mathrm{mmol})$ was added over the course of $1 \mathrm{~h}$. After the addition was completed, the temperature was gradually lowered to room temperature. The solution was continuously stirred for another $3 \mathrm{~h}$ and then quenched with dilute $\mathrm{HCl}$ solution. After the removal of the solvent, the residue was extracted with $\mathrm{CH}_{2} \mathrm{Cl}_{2}(3 \times 60 \mathrm{~mL})$. The extracts were combined, washed twice with water, and dried over anhydrous $\mathrm{MgSO}_{4}$ to afford a yellow solid $(2.4 \mathrm{~g}, 5.4 \mathrm{mmol}, 70 \%)$.

Selected spectral data. $\quad{ }^{1} \mathrm{H}$ NMR $\left(500 \mathrm{MHz}, \mathrm{CDCl}_{3}, 294 \mathrm{~K}\right)$ : $\delta 16.87(\mathrm{~s}, 1 \mathrm{H}), 8.69\left(\mathrm{~d}, J_{\mathrm{HH}}=7.5 \mathrm{~Hz}, 1 \mathrm{H}\right), 8.13\left(\mathrm{~d}, J_{\mathrm{HH}}=7.5 \mathrm{~Hz}\right.$, $1 \mathrm{H}), 7.98\left(\mathrm{~d}, J_{\mathrm{HH}}=8.7 \mathrm{~Hz}, 2 \mathrm{H}\right), 7.87\left(\mathrm{dd}, J_{\mathrm{HH}}=7.5,4.5 \mathrm{~Hz}\right.$, $1 \mathrm{H}), 7.49(\mathrm{~s}, 1 \mathrm{H}), 7.42\left(\mathrm{dd}, J_{\mathrm{HH}}=7.5,4.5 \mathrm{~Hz}, 1 \mathrm{H}\right), 6.68\left(\mathrm{~d}, J_{\mathrm{HH}}=\right.$ $8.7 \mathrm{~Hz}, 2 \mathrm{H}), 3.77\left(\mathrm{t}, J_{\mathrm{HH}}=6.0 \mathrm{~Hz}, 4 \mathrm{H}\right), 3.67 \sim 3.63(\mathrm{~m}, 12 \mathrm{H}), 3.61$ (s, 4H).

\section{Synthesis of 3-(4-aza-15-crown-5-phenyl) pyridyl pyrazole}

A solution of [3-(4-aza-15-crown-5-phenyl) pyridyl(1,3-dione)] $(1.7 \mathrm{~g}, 3.8 \mathrm{mmol})$ and $98 \%$ of hydrazine monohydrate $(1.94 \mathrm{~mL})$ in $45 \mathrm{~mL}$ of anhydrous ethanol was refluxed for $12 \mathrm{~h}$. Next, the solvent was removed under vacuum, and the residue was dissolved in $\mathrm{CH}_{2} \mathrm{Cl}_{2}$, washed twice with water, dried over anhydrous $\mathrm{MgSO}_{4}$, and the solution was concentrated to dryness. The crude product was purified by silica gel column chromatography (ethyl acetate and methanol $=5: 1, \mathrm{v} / \mathrm{v}$ ), giving a light yellow powdery material (azppz)H (1.2 g, $2.74 \mathrm{mmol}, 71 \%)$.

Selected spectral data. ${ }^{1} \mathrm{H}$ NMR $\left(500 \mathrm{MHz}, \mathrm{CDCl}_{3}, 294 \mathrm{~K}\right)$ : $\delta 8.6\left(\mathrm{~d}, J_{\mathrm{HH}}=4.5 \mathrm{~Hz}, 1 \mathrm{H}\right), 7.79 \sim 7.72(\mathrm{~m}, 2 \mathrm{H}), 7.61\left(\mathrm{~d}, J_{\mathrm{HH}}=\right.$ $9.0 \mathrm{~Hz}, 2 \mathrm{H}), 7.21\left(\mathrm{t}, J_{\mathrm{HH}}=4.5 \mathrm{~Hz}, 1 \mathrm{H}\right), 6.96(\mathrm{~s}, 1 \mathrm{H}), 6.79\left(\mathrm{~d}, J_{\mathrm{HH}}=\right.$ $9.0 \mathrm{~Hz}, 2 \mathrm{H}), 3.76\left(\mathrm{t}, J_{\mathrm{HH}}=6.2 \mathrm{~Hz}, 4 \mathrm{H}\right), 3.66 \sim 3.60(\mathrm{~m}, 16 \mathrm{H})$.

\section{Preparation of $\left[(p d p z)_{2} \operatorname{Ir}(\operatorname{azppz})\right](1)$}

A mixture of $\left[(\mathrm{pdpz})_{2} \mathrm{IrCl}\right]_{2}(100 \mathrm{mg}, 0.088 \mathrm{mmol})$, azacrown substituted pyridyl pyrazole (azppzH, $85 \mathrm{mg}, 0.19 \mathrm{mmol})$ and $\mathrm{Na}_{2} \mathrm{CO}_{3}$ (93 mg, $\left.0.88 \mathrm{mmol}\right)$ in 2-methoxyethanol $(25 \mathrm{~mL})$ was heated to reflux for $4 \mathrm{~h}$. Excess of water was added after cooling the solution to room temperature. The precipitate was collected by filtration and subjected to silica gel column chromatography using ethyl acetate and methanol $(5: 1)$ as eluent. Yellow-green crystals of $\left[(\mathrm{pdpz})_{2} \operatorname{Ir}(\mathrm{azppz})\right]$ (1) were obtained from repeated recrystallization using a mixture of $\mathrm{THF}$ and pentane at room temperature (70 mg, $0.07 \mathrm{mmol}, 41 \%$ ).

Spectral data of 1. MS (FAB, $\left.{ }^{193} \mathrm{Ir}\right)$ actual $\mathrm{m} / \mathrm{z}$ (calculated) [assignment]: 973 (972.4) [M + 1]. ${ }^{1} \mathrm{H}$ NMR (500 MHz, $\mathrm{CD}_{2} \mathrm{Cl}_{2}$, $294 \mathrm{~K}): \delta 7.68 \sim 7.61(\mathrm{~m}, 3 \mathrm{H}), 7.52\left(\mathrm{~d}, J_{\mathrm{HH}}=8.5 \mathrm{~Hz}, 2 \mathrm{H}\right), 7.41$ $\left(\mathrm{dd}, J_{\mathrm{HH}}=9.0,8.5 \mathrm{~Hz}, 2 \mathrm{H}\right), 6.97 \sim 6.92(\mathrm{~m}, 2 \mathrm{H}), 6.86(\mathrm{~s}, 1 \mathrm{H}), 6.79$ $\left(\mathrm{t}, J_{\mathrm{HH}}=6.3 \mathrm{~Hz}, 1 \mathrm{H}\right), 6.78 \sim 6.71(\mathrm{~m}, 2 \mathrm{H}), 6.58\left(\mathrm{~d}, J_{\mathrm{HH}}=8.5 \mathrm{~Hz}\right.$, $2 \mathrm{H}), 6.42\left(\mathrm{~d}, J_{\mathrm{HH}}=7.5 \mathrm{~Hz}, 1 \mathrm{H}\right), 6.31\left(\mathrm{~d}, J_{\mathrm{HH}}=7.5 \mathrm{~Hz}, 1 \mathrm{H}\right), 5.98$ $(\mathrm{s}, 1 \mathrm{H}), 5.94(\mathrm{~s}, 1 \mathrm{H}), 3.68\left(\mathrm{t}, J_{\mathrm{HH}}=6.0 \mathrm{~Hz}, 4 \mathrm{H}\right), 3.60 \sim 3.57(\mathrm{~m}$, $8 \mathrm{H}), 3.56(\mathrm{~s}, 4 \mathrm{H}), 3.52\left(\mathrm{t}, J_{\mathrm{HH}}=6.0 \mathrm{~Hz}, 4 \mathrm{H}\right), 2.79(\mathrm{~s}, 3 \mathrm{H}), 2.74(\mathrm{~s}$,
$3 \mathrm{H}), 1.61(\mathrm{~s}, 3 \mathrm{H}), 1.57(\mathrm{~s}, 3 \mathrm{H})$. Anal. calcd. for $\mathrm{C}_{46} \mathrm{H}_{51} \operatorname{IrN}_{8} \mathrm{O}_{4}: \mathrm{C}$, 56.83; H, 5.29; N, 11.53. Found: C, 57.01; H, 5.13; N, 11.73.

Single crystal X-ray diffraction data were acquired on a Bruker Smart CCD diffractometer using $\lambda\left(\mathrm{Mo} \mathrm{K}_{\alpha}\right)$ radiation $(\lambda=$ $0.71073 \AA$ A). Data collection was executed using the SMART program. Cell refinement and data reduction were made with the SAINT program. The structure was determined using the SHELXTL/PC program and refined using full-matrix least squares. All non-hydrogen atoms were refined anisotropically, whereas hydrogen atoms were placed at the calculated positions and included in the final stage of refinements with fixed parameters. Selected crystal data of $\mathbf{1}: \mathrm{C}_{58} \mathrm{H}_{77} \mathrm{IrN}_{8} \mathrm{O}_{8}, \mathrm{M}=1206.48$, triclinic, space group $P-1, a=10.3194(7), b=16.8549(12), c=18.3003(13)$ $\AA, \alpha=63.527(2), \beta=89.840(2), \gamma=76.006(2)^{\circ}, V=2744.4(3)$ $\AA^{3}, Z=2, \rho_{\text {calcd }}=1.460 \mathrm{gcm}^{-1}, F(000)=1244$, crystal size $=$ $0.35 \times 0.17 \times 0.08 \mathrm{~mm}, \lambda\left(\mathrm{Mo} \mathrm{K}_{\alpha}\right)=0.7107 \AA, T=150(1) \mathrm{K}, \mu=$ $2.495 \mathrm{~mm}^{-1}, 12566$ reflections collected $\left(R_{\text {int }}=0.0645\right)$, final $R_{1}[I$ $>2((I)]=0.0558$ and $w R_{2}($ all data $)=0.1406$.

\section{Preparation of $\left[(\mathrm{pdpz})_{2} \operatorname{Ir}(\mathrm{dappz})\right](2)$}

A mixture of $\left[(\mathrm{pdpz})_{2} \mathrm{IrCl}\right]_{2}(100 \mathrm{mg}, 0.088 \mathrm{mmol}), \mathrm{NMe}_{2}$ substituted pyridyl pyrazole (dappzH, $51 \mathrm{mg}, 0.19 \mathrm{mmol}$ ) and $\mathrm{Na}_{2} \mathrm{CO}_{3}$ (93 mg, $0.88 \mathrm{mmol})$ in 2-methoxyethanol $(25 \mathrm{~mL})$ was heated to reflux for $4 \mathrm{~h}$. Excess of water was added after cooling the solution to room temperature. The precipitate was collected by filtration and subjected to silica gel column chromatography using ethyl acetate and methanol $(5: 1)$ as the eluent. Yellow-green powders of $\left[(\mathrm{pdpz})_{2} \operatorname{Ir}(\mathrm{dappz})\right](\mathbf{2})$ were collected after washing with acetone; yield: $50 \mathrm{mg}, 0.063 \mathrm{mmol}, 36 \%$.

Spectral data of 2. MS (FAB, ${ }^{193} \mathrm{Ir}$ ): actual $\mathrm{m} / \mathrm{z}$ (calculated) [assignment]: 799 (798.3) [M + 1]. ${ }^{1} \mathrm{H}$ NMR (500 MHz, $\mathrm{CD}_{2} \mathrm{Cl}_{2}$, $294 \mathrm{~K}): \delta 7.68 \sim 7.61(\mathrm{~m}, 3 \mathrm{H}), 7.52\left(\mathrm{~d}, J_{\mathrm{HH}}=8.5 \mathrm{~Hz}, 2 \mathrm{H}\right), 7.41$ $\left(\mathrm{dd}, J_{\mathrm{HH}}=9.0,8.5 \mathrm{~Hz}, 2 \mathrm{H}\right), 6.96 \sim 6.92(\mathrm{~m}, 2 \mathrm{H}), 6.87(\mathrm{~s}, 1 \mathrm{H}), 6.79$ $\left(\mathrm{t}, J_{\mathrm{HH}}=6.5 \mathrm{~Hz}, 1 \mathrm{H}\right), 6.77 \sim 6.71(\mathrm{~m}, 2 \mathrm{H}), 6.66\left(\mathrm{~d}, J_{\mathrm{HH}}=8.5 \mathrm{~Hz}\right.$, $2 \mathrm{H}), 6.42\left(\mathrm{~d}, J_{\mathrm{HH}}=7.5 \mathrm{~Hz}, 1 \mathrm{H}\right), 6.31\left(\mathrm{~d}, J_{\mathrm{HH}}=7.5 \mathrm{~Hz}, 1 \mathrm{H}\right), 5.98$ (s, 1H), $5.94(\mathrm{~s}, 1 \mathrm{H}), 2.89(\mathrm{~s}, 6 \mathrm{H}), 2.79(\mathrm{~s}, 3 \mathrm{H}), 2.74(\mathrm{~s}, 3 \mathrm{H}), 1.62(\mathrm{~s}$, $3 \mathrm{H}), 1.57$ (s, 3H). Anal. calcd. for $\mathrm{C}_{38} \mathrm{H}_{37} \mathrm{IrN}_{8}$ : C, 57.20; H, 4.67; N, 14.04. Found: C, 57.52; H, 4.43; N, 14.33.

\section{Preparation of $\left[\mathrm{Ph}_{2} \mathrm{~B}(\mathrm{azppz})\right]$ (3)}

In a $50 \mathrm{~mL}$ reaction flask, a mixture of azacrown substituted pyridyl pyrazole (azppzH, $219 \mathrm{mg}, 0.5 \mathrm{mmol}), 4.4 \mathrm{~mL}$ of $2.5 \mathrm{M}$ $\mathrm{BPh}_{3}$, and $20 \mathrm{~mL}$ of anhydrous THF solvent was heated to reflux for $24 \mathrm{~h}$. The solution was then concentrated to dryness and an orange-red crystalline solid of $\mathbf{3}$ was obtained from recrystallization using a mixture of $\mathrm{CH}_{2} \mathrm{Cl}_{2}$ and methanol $(100 \mathrm{mg}$, $0.166 \mathrm{mmol}, 33 \%$ ).

Spectral data of 3. $\mathrm{MS}\left(\mathrm{FAB},{ }^{11} \mathrm{~B}\right)$, actual $\mathrm{m} / \mathrm{z}$ (calculated) [assignment]: 602 (602.3) [ $\mathrm{M}^{+}$]. ${ }^{1} \mathrm{H}$ NMR (500 MHz, $\mathrm{CD}_{2} \mathrm{Cl}_{2}, 294$ $\mathrm{K}): \delta 8.47(\mathrm{~d}, J=7.5 \mathrm{~Hz}, 1 \mathrm{H}), 8.08(\mathrm{~m}, 1 \mathrm{H}), 7.84(\mathrm{~d}, J=7.5 \mathrm{~Hz}$, $1 \mathrm{H}), 7.32(\mathrm{~d}, J=8.5 \mathrm{~Hz}, 2 \mathrm{H}), 7.40 \sim 7.37(\mathrm{~m}, 1 \mathrm{H}), 7.30 \sim 7.28$ $(\mathrm{m}, 4 \mathrm{H}), 7.24 \sim 7.18(\mathrm{~m}, 6 \mathrm{H}), 6.95(\mathrm{~s}, 1 \mathrm{H}), 6.68(\mathrm{~d}, J=8.5 \mathrm{~Hz}$, $2 \mathrm{H}), 3.72(\mathrm{t}, J=6.2 \mathrm{~Hz}, 4 \mathrm{H}), 3.61 \sim 3.60(\mathrm{~m}, 8 \mathrm{H}), 3.58 \sim 3.55$ $(\mathrm{m}, 8 \mathrm{H})$. Anal. calcd. for $\mathrm{C}_{36} \mathrm{H}_{39} \mathrm{BN}_{4} \mathrm{O}_{4}: \mathrm{C}, 71.76 ; \mathrm{H}, 6.52 ; \mathrm{N}, 9.30$. Found: C, 71.40; H, 6.61; N, 9.27. 


\section{Measurements}

Steady-state absorption and emission spectra were recorded by a Hitachi (U-3310) spectrophotometer and an Edinburgh (FS920) fluorimeter, respectively. Emission quantum yields were measured at excitation wavelength $\lambda_{\mathrm{exc}}=380 \mathrm{~nm}$ in $\mathrm{CH}_{2} \mathrm{Cl}_{2}$ at room temperature. In this approach, coumarin 480 (Exciton, $\Phi_{\mathrm{r}}=0.93$ in EtOH) was used as the reference. The association constant $K_{\text {a }}$ of $1: 11$ /guest complex formation calculated by the UV-Vis absorption method is obtained by the following equation. ${ }^{14}$

$$
\frac{A_{0}}{A_{0}-A}=\left(\frac{\varepsilon_{\mathrm{M}}}{\varepsilon_{\mathrm{M}}-\varepsilon_{\mathrm{p}}}\right)\left[\frac{1}{K_{\mathrm{a}} C_{\mathrm{g}}}+1\right]
$$

where $C_{\mathrm{g}}$ is the added guest $\left(\right.$ e.g. $\left.\mathrm{Ca}^{2+}\right)$ concentration. $A_{0}\left(\varepsilon_{\mathrm{M}}\right)$ and $A\left(\varepsilon_{\mathrm{P}}\right)$ denote the absorbance (molar extinction coefficient) of free $\mathbf{1}$, and in solution after adding e.g. $\mathrm{Ca}^{2+}$, respectively, at a selective wavelength. Eqn. (1) can be further extended to the emission titration experiment expressed as ${ }^{14}$

$$
\frac{F_{0}}{F_{0}-F}=\frac{\Phi_{\mathrm{M}} \varepsilon_{\mathrm{M}}}{\left(\Phi_{\mathrm{M}} \varepsilon_{\mathrm{M}}-\Phi_{\mathrm{p}} \varepsilon_{\mathrm{p}}\right)}\left(\frac{1}{K_{\mathrm{a}} C_{\mathrm{g}}}+1\right)
$$

where $F_{0}\left(\Phi_{\mathrm{M}}\right)$ and $F\left(\Phi_{\mathrm{P}}\right)$ denote the photoluminescence (quantum yield) of free $\mathbf{1}$, and in solution after adding $\mathrm{Ca}^{2+}$, respectively, at a selective wavelength.

For the phosphorescence lifetime measurements in the microsecond region, a third harmonic of an Nd:YAG laser $355 \mathrm{~nm}(\sim 8 \mathrm{~ns})$ was used as an excitation source. Emission decay was detected by a photomultiplier tube and averaged over 500 shots using an oscilloscope. Laser energy was reduced to $<1 \mathrm{~mJ}$ pulse $^{-1}$ to prevent possible photochemical decomposition. For the lifetime measurements of $<10 \mathrm{~ns}$, the fundamental train of pulses from a Ti-sapphire oscillator (82 $\mathrm{MHz}$, Spectra Physics) was used to produce second harmonics $(375 \sim 425 \mathrm{~nm}, \sim 120 \mathrm{fs})$ as an excitation light source. The signal was detected by a timecorrelated single photon counting system (Edinburgh OB 900-L). The system response time was determined to be $\sim 30 \mathrm{ps}$.

\section{Computational methodology}

All calculations were performed with the Gaussian03 package. ${ }^{15}$ Geometrical optimization on the electronic ground state was carried out using the hybrid Hartree-Fock/Density functional theory (HF/DFT) method, B3LYP. ${ }^{16}$ "Double- $\zeta$ " quality basis set consisting of Hay and Wadt's effective core potentials $\left(\right.$ LANL2DZ) ${ }^{17}$ was employed for iridium atom and $6-31 \mathrm{G}^{*}$ basis $^{18}$ for $\mathrm{H}, \mathrm{C}$, and $\mathrm{N}$ atoms. A relativistic effective core potential (ECP) replaced the inner core electrons of $\operatorname{Ir}(\mathrm{III})$, leaving the outer core $\left(5 s^{2} 5 p^{6}\right)$ electrons and the $5 d^{6}$ valence electrons. Time-dependent DFT (TDDFT) calculations were then performed with the same functional and basis set at the optimized geometry to obtain electronic transition energies. Oscillator strengths were deduced from the dipole transition matrix elements (for singlet states only).

\section{Results and discussion}

A multi-step synthetic pathway leading to the desired iridium metal complexes is depicted in Scheme 1. First of all, an azacrown substituted pyridyl pyrazole ligand, (azppz)H, was obtained from the condensation reaction of an azacrown substituted acetophenone and ethyl picolinate, followed by treatment

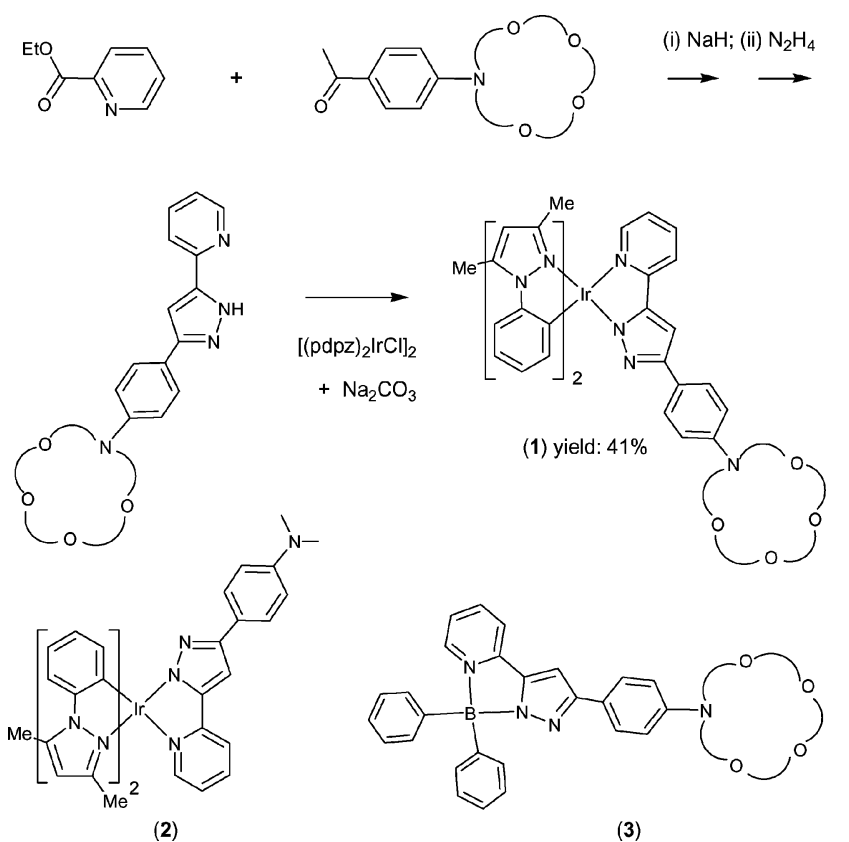

Scheme 1 Synthetic scheme of $\mathbf{1}$ and molecular structures of $\mathbf{2}$ and $\mathbf{3}$.

with hydrazine monohydrate in ethanol solution (Scheme 1). The subsequent reaction of (azppz)H with the chloride bridged dimer complex $\left[(\mathrm{pdpz})_{2} \mathrm{IrCl}\right]_{2}$ and slight excess of $\mathrm{Na}_{2} \mathrm{CO}_{3}$ in refluxing methoxyethanol solution afforded the required iridium chelate complex [(pdpz) $\left.)_{2} \operatorname{Ir}(\mathrm{azppz})\right](\mathbf{1})$, where (pdpz)H = 1-phenyl3,5-dimethyl pyrazole. Moreover, the analogous dimethylamino substituted iridium derivative (2) and a $\mathrm{BPh}_{2}$ substituted complex (3) (see Scheme 1) bearing identical azppz pyrazolate ligand were synthesized from reaction with the boron reagent $\mathrm{BPh}_{3}$, and these then served as the standards for photophysical measurements.

As indicated in Fig. 1, single crystal X-ray structural analysis of 1 shows the expected octahedral geometry around the iridium metal center, along with two $N$-phenyl pyrazole fragments and one azacrown substituted pyridyl pyrazolate ligand. The cyclometalated $N$-phenyl pyrazoles adopt an eclipse orientation, while the azacrown pyrazolate chelate is located opposite to the cyclometalated carbon atoms, with the spatial arrangement being akin to those observed for other heteroleptic pyridyl pyrazolate

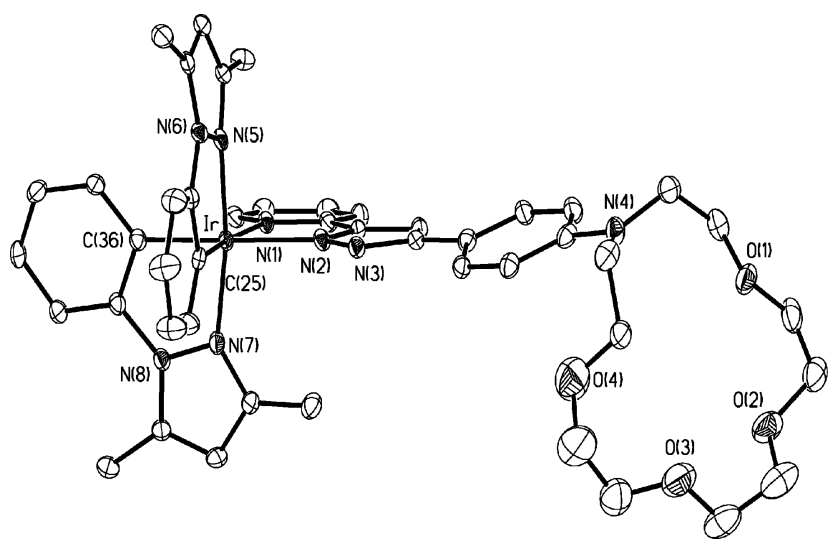

Fig. 1 The X-ray crystal structure of $\mathbf{1}$; selected distances: $\mathrm{Ir}-\mathrm{C}(25)=$ 1.984(6), $\operatorname{Ir}-\mathrm{C}(36)=2.020(6), \operatorname{Ir}-\mathrm{N}(1)=2.155(5), \operatorname{Ir}-\mathrm{N}(2)=2.112(5)$, $\operatorname{Ir}-\mathrm{N}(5)=2.023(5)$ and 2.021(5) $\AA$. 
complexes. ${ }^{19}$ Moreover, the azacrown fragment shows unusually large deformation toward the iridium metal fragment, for which the calculated dihedral angle between the adjacent $p$-phenyl group and the $\mathrm{O}_{4} \mathrm{~N}$ plane of azacrown is $117.5^{\circ}$.

As shown in Fig. 2, ion-free 1 in $\mathrm{CH}_{3} \mathrm{CN}$ exhibits a $318 \mathrm{~nm}$ absorption band, accompanied by a shoulder at $\sim 375 \mathrm{~nm}$. In comparison, the boron complex 3 bearing the same pyridyl pyrazolate ligand reveals two low-lying absorption bands with peak wavelengths at 315 and $375 \mathrm{~nm}$, the spectral features of which are similar to that of complex 1. Due to lack of both MLCT and the transition associated with cyclometalated phenyl pyrazole ligand in boron complex 3, it is reasonable to assign both 315 and $375 \mathrm{~nm}$ bands as the ${ }^{1} \pi \pi^{*}$ transitions incorporating pyrazolates $\rightarrow$ pyridyl types of charge transfer. Transitions associated with MLCT in 1 are probably too weak and thus are hidden inside the ${ }^{1} \pi \pi^{*}$ bands. Further firm support is given in the theoretical approaches (vide infra). Likewise, absorption features associated with the ${ }^{3} \pi \pi^{*}$ intra-ligand bands and ${ }^{3}$ MLCT could not be resolved although an effective enhancement of the spin-orbit coupling from Ir is expected.

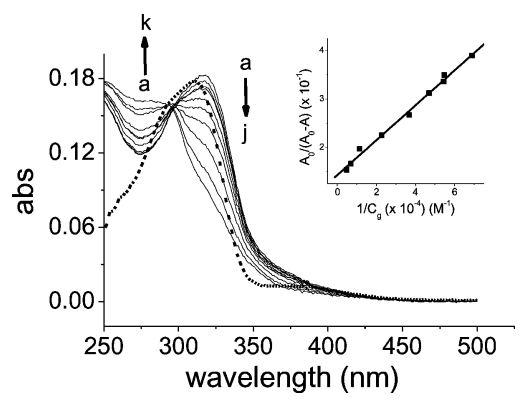

Fig. 2 Absorption spectrum changes of $\mathbf{1}\left(2.2 \times 10^{-5} \mathrm{M}\right)$ upon addition of various concentrations of anhydrous $\mathrm{Ca}\left(\mathrm{ClO}_{4}\right)_{2}$ in aerated $\mathrm{CH}_{3} \mathrm{CN}$ solution (a) 0 , (b) $1.45 \times 10^{-5}$, (c) $1.83 \times 10^{-5}$, (d) $1.84 \times 10^{-5}$, (e) $2.13 \times$ $10^{-5}$, (f) $2.71 \times 10^{-5}$, (g) $4.39 \times 10^{-5}$, (h) $8.70 \times 10^{-5}$, (i) $1.45 \times 10^{-4}$, (j) $2.03 \times 10^{-4}$ M. (---) absorption spectrum of 3 in $\mathrm{CH}_{3} \mathrm{CN}$. Insert: the plot of $A_{0} / A_{0}-A$ against $1 /\left[\mathrm{Ca}^{2+}\right]$ at $320 \mathrm{~nm}$.

The emission spectrum of $\mathbf{1}$ in $\mathrm{CH}_{3} \mathrm{CN}$ is depicted in Fig. 3 and the corresponding relaxation dynamics are listed in Table 1. The emission band with a peak wavelength at $560 \mathrm{~nm}$ revealed a drastic oxygen quenching effect, the intensity of which decreased from 0.22 in degassed $\mathrm{CH}_{3} \mathrm{CN}$, to $\sim 1.0 \times 10^{-3}$ upon aeration.

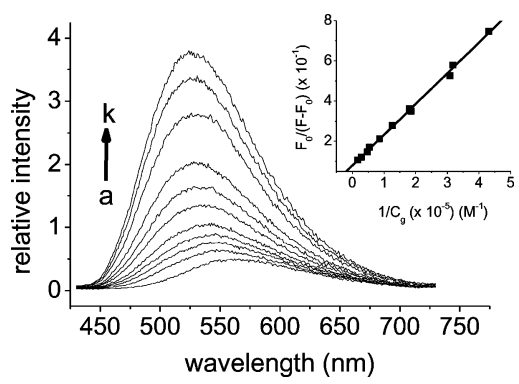

Fig. 3 The emission spectrum changes of $1\left(2.2 \times 10^{-5} \mathrm{M}\right)$ upon addition of various concentrations of anhydrous $\mathrm{Ca}\left(\mathrm{ClO}_{4}\right)_{2}$ in aerated $\mathrm{CH}_{3} \mathrm{CN}$ solution (a) 0 , (b) $3.15 \times 10^{-6}$, (c) $3.25 \times 10^{-6}$, (d) $5.40 \times 10^{-6}$, (e) $5.57 \times$ $10^{-6}$, (f) $7.89 \times 10^{-6}$, (g) $1.16 \times 10^{-5}$, (h) $2.09 \times 10^{-5}$, (i) $3.48 \times 10^{-5}$, (j) $5.8 \times 10^{-5}$, (k) $1.85 \times 10^{-4}$ M. $\lambda_{\text {ex }}: 300 \mathrm{~nm}$. Insert: the plot of $F_{0} / F-$ $F_{0}$ against $1 / C_{\mathrm{g}}$ at $520 \mathrm{~nm}$.
Table 1 Photophysical data of $\mathbf{1}$ and the respective cationic adducts

\begin{tabular}{lllll}
\hline & PL $\lambda_{\max }$ & $Q . Y^{a}$ & lifetime $(\tau)^{a}$ & $K_{\mathrm{a}}$ \\
\hline $\mathbf{1}$ & $560 \mathrm{~nm}$ & $0.001(0.22)$ & $38 \mathrm{~ns}(8.2 \mu \mathrm{s})$ & \\
$\mathbf{1} / \mathbf{C a}^{2+}$ & $520 \mathrm{~nm}$ & $0.012(0.20)$ & $42 \mathrm{~ns}(0.6 \mu \mathrm{s})$ & $4.2 \times 10^{4}$ \\
$\mathbf{1} / \mathbf{M g}^{2+}$ & $518 \mathrm{~nm}$ & $0.013(0.23)$ & $48 \mathrm{~ns}(0.8 \mu \mathrm{s})$ & $1.6 \times 10^{5}$ \\
$\mathbf{1} / \mathbf{B a}^{2+}$ & $521 \mathrm{~nm}$ & $0.010(0.20)$ & $41 \mathrm{~ns}(0.6 \mu \mathrm{s})$ & $5.3 \times 10^{3}$ \\
$\mathbf{1} / \mathbf{N a}^{+}$ & $520 \mathrm{~nm}$ & $0.012(0.18)$ & $40 \mathrm{~ns}(0.5 \mu \mathrm{s})$ & $4.7 \times 10^{3}$
\end{tabular}

${ }^{a}$ data in parentheses are measured in the degassed solution.

Likewise, the corresponding observed lifetime decreased from $8 \mu \mathrm{s}$ (degassed) to $38 \mathrm{~ns}$ (aerated, see Table 1). The $\sim 1 / 9$ diffusion controlled rate of $\mathrm{O}_{2}$ quenching, in combination with a long radiative decay rate of $3.5 \times 10^{4} \mathrm{~s}^{-1}$, leads to an unambiguous conclusion that $\mathbf{1}$ exhibits predominantly the phosphorescence resulting from the enhancement of Ir(III) spin-orbit coupling.

Upon addition of $\mathrm{Ca}^{2+}$, the absorption and emission titration spectra of $1\left(2.2 \times 10^{-5} \mathrm{M}\right)$ in $\mathrm{CH}_{3} \mathrm{CN}$ are shown in Figs. 2 and 3, respectively. Increasing $\left[\mathrm{Ca}^{2+}\right]$ leads to a hypsochromic shift of the absorption profile, in which the appearance of an isosbestic point at $\sim 295 \mathrm{~nm}$ verifies a two-species equilibrium. The $1: 11 / \mathrm{Ca}^{2+}$ complexation was supported by a straight-line plot for the ratio of absorbance, $A_{0} /\left(A_{0}-A\right)$, versus $1 /\left[\mathrm{Ca}^{2+}\right]$ (see the experimental section) throughout the titration, and an association constant $K_{\mathrm{a}}$ of $4.0 \times 10^{4} \mathrm{M}^{-1}$ was thus deduced in $\mathrm{CH}_{3} \mathrm{CN}$. Likewise, drastic changes on the $\mathrm{Ca}^{2+}$ phosphorescence titration spectra were also observed. Upon excitation at the isosbestic point of $295 \mathrm{~nm}$, the $560 \mathrm{~nm}$ phosphorescence was gradually blue shifted toward $520 \mathrm{~nm}$, accompanied by the increase of the emission intensity. Taking the emission peak intensity of $\mathrm{Ca}^{2+}$-free and $\mathrm{Ca}^{2+}$-added complex 1 to be $F_{0}$ and $F$, respectively, a straight line plot of $F_{0} /\left(F-F_{0}\right)$ versus $1 /\left[\mathrm{Ca}^{2+}\right]$ (see the experimental section) at e.g. $520 \mathrm{~nm}$ is depicted in the insert of Fig. 3. The deduced $K_{\text {a }}$ value of $4.2 \times 10^{4} \mathrm{M}^{-1}$, within experimental error, is in agreement with that extracted from the absorption titration.

It should be noted that both complexes $\mathbf{2}$ and $\mathbf{3}$ showed negligible changes in their absorption and emission spectra upon addition of $\mathrm{Ca}^{2+}$, manifesting the importance of the coexistence of Ir and 1-aza-15-crown-5-ether in complex 1 toward the $\mathrm{Ca}^{2+}$ recognition. The results can be rationalized by weakening the electron donating ability of the aza-nitrogen upon $\mathrm{Ca}^{2+} /$ azacrown complex formation and consequently greatly alters the photophysical properties of $\mathbf{1}$. This viewpoint can be firmly supported by theoretical modelling. Presently, ab initio calculation on $\mathbf{1}$ is formidable due to its structural complexity. Alternatively, the dimethyl amino analogue $\mathbf{2}$ was selected, of which the major ligand chromophores remain intact with respect to $\mathbf{1}$. Furthermore, the protonated form of $\mathbf{2}, \mathbf{2} \mathbf{H}^{+}$, serves as a model for the $\mathrm{Ca}^{2+}$ bonded complex 1 . We then applied density functional theory incorporating B3LYP method with $6-31 \mathrm{G}^{*}$ basis for non-metal atoms and a relativistic effective core potential for the inner core electrons of $\operatorname{Ir}(\mathrm{III})$ metal atom. The resulting frontier orbitals for the low-lying transitions revealed drastic differences between 2 and $\mathbf{2} \mathbf{H}^{+}$. As shown in Fig. 4, the lowest triplet manifold for $\mathbf{2}$ exhibits predominantly $\mathrm{HOMO} \rightarrow$ LUMO intraligand charge transfer (ILCT) transition, in which HOMO and LUMO are mainly located at the phenyl pyrazolate and pyridyl chromophores, respectively. In sharp contrast, upon protonation $\left(\mathbf{2 H}^{+}\right)$the 


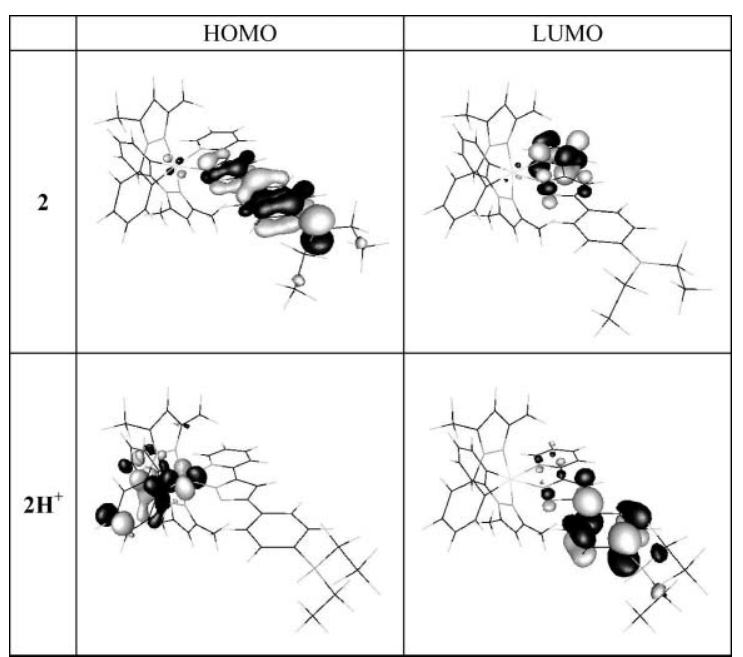

Fig. 4 Frontier orbitals of complexes $\mathbf{2}$ and $\mathbf{2} \mathbf{H}^{+}$, see text for detail description.

transition switches greatly to a ligand-ligand charge transfer (LLCT) incorporating cyclometalated phenyl pyrazole ligand $(\mathrm{HOMO}) \rightarrow$-dialkylamino-phenyl pyrazolate (LUMO). Assuming that the differences in photophysical behavior between $\mathbf{2}$ and $\mathbf{2} \mathbf{H}^{+}$can be likewise applied to $\mathbf{1}$ and $\mathbf{1} / \mathrm{Ca}^{2+}$ complex, changes of absorption and emission spectra during $\mathrm{Ca}^{2+}$ titration are thus be rationalized by the swap of lowest transition from ILCT ( $p$-dialkylaminophenyl pyrazolate $\rightarrow$ pyridine) in $\mathbf{1}$ to LLCT (cyclometalated phenyl pyrazolate $\rightarrow p$-dialkylaminophenyl pyrazolate) in $\mathbf{1} / \mathrm{Ca}^{2+}$ complex.

Similar titration experiments have been performed for the hard, bivalent metal cation such as $\mathrm{Mg}^{2+}$ and $\mathrm{Ba}^{2+}$ and $K_{\mathrm{a}}$ values of $1.6 \times 10^{5} \mathrm{M}^{-1}$ and $5.3 \times 10^{3} \mathrm{M}^{-1}$, respectively, were obtained. In another approach, negligible changes of absorption spectra were observed for soft divalent ions like $\mathrm{Hg}^{2+}$. Titration experiments were also performed for $\mathrm{Na}^{+}$and the results indicated a $K_{\mathrm{a}}$ value of $4.7 \times 10^{3} \mathrm{M}^{-1}$ for the $1 / \mathrm{Na}^{+}$complex formation. The resulting metal ion dependent association strengths can be qualitatively rationalized by the amount of charge density, $\rho$, specified as $\rho=$ $g /\left(4 / 3 \pi r^{3}\right)$ where $g$ and $r$ are the corresponding formal charge $(+1$ or +2$)$ and radius, respectively. Evidently, the value of $\rho\left(\mathrm{Mg}^{2+} \sim\right.$ $0.75, \mathrm{Ca}^{2+} \sim 0.24, \mathrm{Na}^{+} \sim 0.10$ and $\left.\mathrm{Ba}^{2+} \sim 0.13\right)^{20}$ correlates well with the trend of $K_{\mathrm{a}}$ values deduced experimentally (see Table 1). Furthermore, negligible spectral changes were observed for $\mathrm{K}^{+}$ throughout $\left[\mathrm{K}^{+}\right]$of $10^{-2} \mathrm{M}$. This result can simply be rationalized by the mismatched sizes between $\mathrm{K}^{+}$and the 1-aza-15-crown-5 ether.

In solid form 1 exhibits a $565 \mathrm{~nm}$ phosphorescent emission with a quantum yield as high as $0.25\left(\tau_{\mathrm{p}} \sim 12 \mu \mathrm{s}\right)$. Thus, from the viewpoint of application, we have also examined whether a similar recognition capability can be applied in the heterogeneous solid film in aqueous solution. Note that $\mathbf{1}$ is insoluble in water. To simplify the process, a silica-based TLC plate was used as a solid support to soak 1 in $\mathrm{CH}_{3} \mathrm{CN}$ so that a complex 1 coated TLC plate was prepared with an optical density of $\sim 1.0$ at $350 \mathrm{~nm}$. This plate was then dipped into an aqueous solution ( $\mathrm{pH} \sim 7.0)$ containing $\sim 10^{-3} \mathrm{M} \mathrm{CaClO}_{4}$ for $\sim 30 \mathrm{~s}$, and then vacuum-dried to remove water. With the use of a commercially available UV-lamp (366 $\mathrm{nm})$ as an excitation source, a photograph in TOC demonstrates a salient change of emission from yellow-orange for the $\mathrm{Ca}^{2+}$-free, complex 1 coated TLC plate to a bright green emission upon complexation with the $\mathrm{Ca}^{2+}$ ion.

\section{Conclusions}

In conclusion, we demonstrate a novel metal ion sensor, complex $\mathbf{1}$, based on the rare metal-ion sensitive phosphorescence. In this case, the chromophores designed act as both recognition and signaltransducing units, while the center heavy metal, i.e. $\operatorname{Ir}(\mathrm{III})$, serves as a perturbing base to enhance the phosphorescence. Thus, the current system is versatile in that functional derivatization can be achieved with methods similar to those strategically designed for the singlet $\pi \pi^{*}$ (i.e. fluorescence) ligand chromophores. In view of drastic oxygen quenching, in a steady state approach, one can then saturate the solution with $\mathrm{N}_{2}$ so that the enhanced phosphorescence can also serve as an additional signalling to distinguish it from the fluorescence interference. Alternatively, in a time-resolved manner, due to its much longer lifetime (even in the aerated solution) than that of typical fluorescence, the associated phosphorescence can be obtained free from fluorescence interferences in the solution simply by acquiring the phosphorescence only after a certain time delay of the excitation pulse. The success in the recognition of $\mathrm{Ca}^{2+}(\mathrm{aq})$ in the TLC plate demonstrates its suitability for the future development of a practical device, such as a metal ion sensor anchored on cellular membranes. We thus believe that results presented in this study may spark a broad range of interest in both fundamental approach and applications relevant to the third-row transition metal complexes.

\section{Acknowledgements}

This work was funded by the National Science Council of Taiwan, R.O.C. under grants: NSC 93-2113-M-007-012 and NSC 93-2752-M-002-002-PAE. We are also grateful to the National Center for High-Performance Computing for generous amounts of computing time.

\section{References}

1 (a) H.-G. Löhr and F. Vögtle, Acc. Chem. Res., 1985, 18, 65; (b) W.-S. Xia, R. H. Schmehl and C.-J. Li, J. Am. Chem. Soc., 1999, 121, 5599; (c) B. Valeur and I. Leray, Coord. Chem. Rev., 2000, 205, 3; (d) A. P. de Silva, D. B. Fox, A. J. M. Huxley and T. S. Moody, Coord. Chem. Rev., 2000, 205, 41; (e) A. P. de Silva, D. B. Fox, T. S. Moody and S. M. Weir, Pure Appl. Chem., 2001, 73, 503.

2 (a) K. S. Schanze, D. B. MacQueen, T. A. Perkins and L. A. Cabana, Coord. Chem. Rev., 1993, 122, 63; (b) G. W. Gokel, W. M. Leevy and M. E. Weber, Chem. Rev., 2004, 104, 2723; (c) S.-W. Lai and C.-M. Che, Top. Curr. Chem., 2004, 241, 27.

3 (a) A. P. de Silva, H. Q. Nimal Gunaratne, T. Gunnlaugsson, A. J. M. Huxley, C. P. McCoy, J. T. Rademacher and T. E. Rice, Chem. Rev, 1997, 97, 1515; (b) P. D. Beer and E. J. Hayes, Coord. Chem. Rev., 2003, 240, 167.

4 (a) R. Slone, D. I. Yoon, R. M. Calhoun and J. T. Hupp, J. Am. Chem. Soc., 1995, 117, 11813; (b) Y. Shen and B. P. Sullivan, Inorg. Chem., 1995, 34, 6235; (c) V. W.-W. Yam, C.-L. Chan, C.-K. Li and K. M.-C. Wong, Coord. Chem. Rev., 2001, 216-217, 173; (d) V. W.-W. Yam, R. P.-L. Tang, K. M.-C. Wong, X.-X. Lu, K.-K. Cheung and N. Zhu, Chem. Eur. J., 2002, 8, 4066; (e) L. J. Charbonniere, R. F. Ziessel, C. A. Sams and A. Harriman, Inorg. Chem., 2003, 42, 3466; (f) P. K. M. Siu, S.-W. Lai, W. Lu, N. Zhu and C.-M. Che, Eur. J. Inorg. Chem., 2003, 2749; (g) Q.-Z. Yang, L.-Z. Wu, H. Zhang, B. Chen, Z.-X. Wu, L.-P. Zhang and C.-H. Tung, Inorg. Chem., 2004, 43, 5195. 
5 (a) D. B. MacQueen and K. S. Schanze, J. Am. Chem. Soc., 1991, 113, 6108; (b) C. E. Whittle, J. A. Weinstein, M. W. George and K. S. Schanze, Inorg. Chem., 2001, 40, 4053.

6 (a) J. F. Michalec, S. A. Bejune, D. G. Cuttell, G. C. Summerton, J. A. Gertenbach, J. S. Field, R. J. Haines and D. R. McMillin, Inorg. Chem., 2001, 40, 2193; (b) J. D. Lewis, L. Bussotti, P. Foggi, R. N. Perutz and J. N. Moore, J. Phys. Chem. A, 2002, 106, 12202; (c) J. D. Lewis and J. N. Moore, Dalton Trans., 2004, 1376; (d) W.-S. Tang, X.-X. Lu, K. M.-C. Wong and V. W.-W. Yam, J. Mater. Chem., 2005, 15, 2714.

7 A. B. Tamayo, B. D. Alleyne, P. I. Djurovich, S. Lamansky, I. Tsyba, N. N. Ho, R. Bau and M. E. Thompson, J. Am. Chem. Soc., 2003, 125, 7377.

8 (a) Y. Shen and B. P. Sullivan, J. Chem. Educ., 1997, 74, 685; (b) P. D. Beer, S. W. Dent, N. C. Fletcher and T. J. Wear, Polyhedron, 1996, 15, 2983; (c) M. E. Padilla-Tosta, J. M. Lloris, R. Martinez-Manez, M. D. Marcos, M. A. Miranda, T. Pardo, F. Sancenon and J. Soto, Eur. J. Inorg. Chem., 2001, 1475.

9 T. Lazarides, T. A. Miller, J. C. Jeffery, T. K. Ronson, H. Adams and M. D. Ward, Dalton Trans., 2005, 528.

10 H. Maeda, S. Furuyoshi, Y. Nakatsuji and M. Okahara, Bull. Chem. Soc. Jpn., 1983, 56, 212.

11 Y. Chen and G. L. Baker, J. Org. Chem., 1999, 64, 6870.

12 K. Y. Lee, J. M. Kim and J. N. Kim, Tetrahedron Lett., 2003, 44, 6737.

13 (a) M. Nonoyama, J. Organomet. Chem., 1975, 86, 263; (b) C.-H. Yang, S.-W. Li, Y. Chi, Y.-M. Cheng, Y.-S. Yeh, P.-T. Chou, G.-H. Lee, C.-H. Wang and C.-F. Shu, Inorg. Chem., 2005, 44, 7770.

14 (a) P.-T. Chou, G.-R. Wu, C.-Y. Wei, C.-C. Cheng, C.-P. Chang and F.-T. Hung, J. Phys. Chem. B, 1999, 103, 10042; (b) P.-T. Chou, G.-R. Wu, C.-Y. Wei, C.-C. Cheng, C.-P. Chang and F.-T. Hung, J. Phys. Chem. $B, 2000,104,7818$.

15 M. J. Frisch, G. W. Trucks, H. B. Schlegel, G. E. Scuseria, M. A. Robb, J. R. Cheeseman, J. A. Montgomery, Jr., T. Vreven, K. N.
Kudin, J. C. Burant, J. M. Millam, S. S. Iyengar, J. Tomasi, V. Barone, B. Mennucci, M. Cossi, G. Scalmani, N. Rega, G. A. Petersson, H. Nakatsuji, M. Hada, M. Ehara, K. Toyota, R. Fukuda, J. Hasegawa, M. Ishida, T. Nakajima, Y. Honda, O. Kitao, H. Nakai, M. Klene, X. Li, J. E. Knox, H. P. Hratchian, J. B. Cross, V. Bakken, C. Adamo, J. Jaramillo, R. Gomperts, R. E. Stratmann, O. Yazyev, A. J. Austin, R. Cammi, C. Pomelli, J. Ochterski, P. Y. Ayala, K. Morokuma, G. A. Voth, P. Salvador, J. J. Dannenberg, V. G. Zakrzewski, S. Dapprich, A. D. Daniels, M. C. Strain, O. Farkas, D. K. Malick, A. D. Rabuck, K. Raghavachari, J. B. Foresman, J. V. Ortiz, Q. Cui, A. G. Baboul, S. Clifford, J. Cioslowski, B. B. Stefanov, G. Liu, A. Liashenko, P. Piskorz, I. Komaromi, R. L. Martin, D. J. Fox, T. Keith, M. A. AlLaham, C. Y. Peng, A. Nanayakkara, M. Challacombe, P. M. W. Gill, B. G. Johnson, W. Chen, M. W. Wong, C. Gonzalez and J. A. Pople, GAUSSIAN 03 (Revision C.02), Gaussian, Inc., Wallingford, CT, 2004.

16 (a) A. D. Becke, J. Chem. Phys., 1993, 98, 5648; (b) C. Lee, W. Yang and R. G. Parr, Phys. Rev. B, 1988, 37, 785.

17 (a) T. H. Dunning and P. J. Hay, In Modern Theoretical Chemistry, ed. H. F. Schaefer, III, Plenum Press, New York, 1976, vol. 3, pp. 11; (b) P. J. Hay and W. R. Wadt, J. Chem. Phys., 1985, 82, 270; (c) W. R. Wadt and P. J. Hay, J. Chem. Phys., 1985, 82, 284; (d) P. J. Hay and W. R. Wadt, J. Chem. Phys., 1985, 82, 299.

18 P. C. Hariharan and J. A. Pople, Mol. Phys., 1974, 27, 209.

19 (a) Y.-H. Song, S.-J. Yeh, C.-T. Chen, Y. Chi, C.-S. Liu, J.-K. Yu, Y.-H. Hu, P.-T. Chou, S.-M. Peng and G.-H. Lee, Adv. Funct. Mater., 2004, 14, 1221; (b) F.-M. Hwang, H.-Y. Chen, P.-S. Chen, C.-S. Liu, Y. Chi, C.-F. Shu, F.-I. Wu, P.-T. Chou, S.-M. Peng and G.-H. Lee, Inorg. Chem., 2005, 44, 1344.

20 Q.-Z. Yang, Q.-X. Tong, L.-Z. Wu, Z. X. Wu, L. P. Zhang and C. H. Tung, Eur. J. Inorg. Chem., 2004, 1948. 